\title{
Perception of the Online Learning Environment of Nursing Students in Slovenia: Validation of the DREEM Questionnaire
}

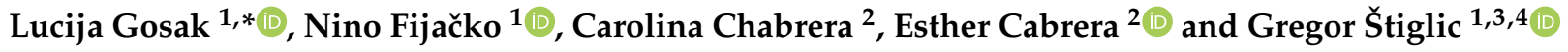 \\ 1 Faculty of Health Sciences, University of Maribor, 2000 Maribor, Slovenia; nino.fijacko@um.si (N.F.); \\ gregor.stiglic@um.si (G.Š.) \\ 2 Research Group in Attention to Chronicity and Innovation in Health (GRACIS), TecnoCampus, Universitat \\ Pompeu Fabra, 08002 Barcelona, Spain; cchabrera@tecnocampus.cat (C.C.); ecabrera@tecnocampus.cat (E.C.) \\ 3 Faculty of Electrical Engineering and Computer Science, University of Maribor, 2000 Maribor, Slovenia \\ 4 Usher Institute, University of Edinburgh, Edinburgh EH8 9YL, UK \\ * Correspondence: lucija.gosak2@um.si; Tel.: +386-2-300-47-35
}

\section{check for} updates

Citation: Gosak, L.; Fijačko, N.; Chabrera, C.; Cabrera, E.; Štiglic, G. Perception of the Online Learning Environment of Nursing Students in Slovenia: Validation of the DREEM Questionnaire. Healthcare 2021, 9, 998. https://doi.org/10.3390/healthcare 9080998

Academic Editors: José João Mendes, Vanessa Machado, João Botelho and Luís Proença

Received: 20 July 2021

Accepted: 1 August 2021

Published: 5 August 2021

Publisher's Note: MDPI stays neutral with regard to jurisdictional claims in published maps and institutional affiliations.

Copyright: (c) 2021 by the authors. Licensee MDPI, Basel, Switzerland. This article is an open access article distributed under the terms and conditions of the Creative Commons Attribution (CC BY) license (https:// creativecommons.org/licenses/by/ $4.0 /)$.

\begin{abstract}
At the time of the outbreak of the coronavirus pandemic, several measures were in place to limit the spread of the virus, such as lockdown and restriction of social contacts. Many colleges thus had to shift their education from personal to online form overnight. The educational environment itself has a significant influence on students' learning outcomes, knowledge, and satisfaction. This study aims to validate the tool for assessing the educational environment in the Slovenian nursing student population. To assess the educational environment, we used the DREEM tool distributed among nursing students using an online platform. First, we translated the survey questionnaire from English into Slovenian using the reverse translation technique. We also validated the DREEM survey questionnaire. We performed psychometric testing and content validation. I-CVI and SCVI are at an acceptable level. A high degree of internal consistency was present, as Cronbach's alpha was 0.951 . The questionnaire was completed by 174 participants, of whom 30 were men and 143 were women. One person did not define gender. The mean age of students was 21.1 years $(\mathrm{SD}=3.96)$. The mean DREEM score was 122.2. The mean grade of student perception of learning was $58.54 \%$, student perception of teachers was $65.68 \%$, student academic self-perception was $61.88 \%$, student perception of the atmosphere was $60.63 \%$, and social self-perception of students was $58.93 \%$. Although coronavirus has affected the educational process, students still perceive the educational environment as positive. Nevertheless, there is still room for improvement in all assessed areas.
\end{abstract}

Keywords: education; learning environment; nursing student; transcultural adaptation; psychometric properties; health care

\section{Introduction}

Due to the coronavirus pandemic (COVID-19), which was reported in Wuhan, China [1-4] and soon after, the first major outbreak in Europe spread rapidly to Slovenia $[5,6]$. Governments issued directives on social isolation and living at home, so colleges and universities around the world were closed [7]. COVID-19 has forced education systems around the world to find alternatives to personal teaching [8]. Online distance learning platforms are the only available way of learning and teaching during unprecedented events such as the outbreak of COVID-19 [9-11]. However, it is important to distinguish between online distance education and distance learning in an emergency as a temporary solution. Online education provides students with flexibility and choice [12]. This involves implementing education using information and communication technology [13] and represents an easily accessible teaching method [14].

Online learning promotes student-centered learning, in which case courses are easy to manage [15], resulting in better knowledge and self-efficacy for some students [16]. It increases performance, encourages critical thinking, and improves writing skills for 
most students [17]. Through the accelerated use of online learning, educators and carers need to consider the pedagogical and practical challenges posed by the integration of online learning [18]. Negative aspects highlighted are a lack of appropriate infrastructure for some students, less effective communication and interaction, inability to implement practical applications, lack of socialization, lack of motivation, less objective exams, and the possibility of deteriorating health [19].

Despite growing evidence that online learning is just as effective as traditional learning tools, there is very little evidence of what works, when, and how online learning improves teaching and learning [20]. Therefore, in this study, we decided to evaluate the online learning environment of students using the Dundee Ready Education Environment Measure (DREEM) tool [21-23]. Any learning environment that meets students' internal and external needs is likely to lead to better and more promising learning outcomes [24]. Achieving an optimal educational environment must meet the expectations of students regarding the school atmosphere, teaching, teachers, students, school staff, educational equipment, and the physical environment [25]. A good learning environment for students in clinical practice depends on the structure of student admission, the pedagogical atmosphere, and the participation of those involved [26]. The educational environment has an impact on students' learning outcomes, preparation for practice, and student satisfaction [27]. Also, the perception of the learning environment is related to well-being and stress in students [28].

The main goal of the research is a validation of the questionnaire focusing on the assessment and perception of nursing students about the online learning environment. The goal is also to test psychometrically the DREEM tool [22,23]. The validation of the DREEM tool is performed within the Erasmus+ project Digital Toolbox for Innovation and Nursing Education (I-BOX), which aims to develop material for teaching nursing students and nurses. Based on the obtained results, we will also assess where the greatest deviations occur in the assessment of the learning environment and thus encourage the improvement of the learning environment for students.

\section{Materials and Methods}

\subsection{Study Design}

We used quantitative research methodology [29-31]. Data for assessing the educational environment by undergraduate and postgraduate nursing students were collected using an online questionnaire between November 2020 and January 2021. The survey questionnaire was previously translated into Slovenian language and validated in the Slovenian environment for the first time.

\subsection{Assessment Tool}

To assess the online educational environment, we used the DREEM tool [22,23]. DREEM is a validated tool for assessing the educational environment in health care professions worldwide [32]. In addition to being used to diagnose deficiencies in the current educational environment, DREEM is also used to compare different groups, monitor the same group over time, and assess factors influencing the educational environment [33,34]. The DREEM tool includes five subscales: students' perception of learning (SPL); students perception of teachers (SPT); students' academic self-perception (SAP); students' perception of the atmosphere (SPA) and students' social self-perception (SSP). The maximum score is 200 [35]. The use of the questionnaire was previously authorized by the authors [22,23]. The survey questionnaire was translated from English into Slovenian and then back to the original language [36]: Independently by two researchers, the survey questionnaire was translated from English into Slovenian. Both researchers had the necessary knowledge of English, andragogy, and nursing. Thus, we obtained two versions of the translation, which we merged into one in the next step, based on consultation between experts. If disagreement was present, a third researcher was involved. In the last step, two experts with the necessary knowledge of English translated a joint version of the Slovenian questionnaire 
into English. Thus, we obtained two forms of reverse translation and subsequently merged them into a common form [29,30].

Questionnaires were distributed using an online survey platform ENKA from which the results were then downloaded and analysed using IBM SPSS Statistics 27.

\subsubsection{Validation of Assessment Tool}

We assessed the validity of the content and the validity of the construct in the survey questionnaire and performed confirmatory factor analysis [37,38]. To determine the content validity, we included experts who have the necessary knowledge in the field [29,30,37,39]. Based on the recommendations where six to ten experts are required [40], we included six experts who work as nursing teachers. The questions in the questionnaire were rated on a four-point scale from 1 to 4 , where 1 represents statements that are not relevant; 2 , deficient/poorly understood statements; 3 , partially understandable/partially relevant statements; and 4, entirely understandable/completely relevant claims [41]. To assess the content validity of the questionnaire, we calculated the content validity of individual claims (I-CVI) and content validity of the whole questionnaire (S-CVI) [41-46]. For the internal reliability analysis, we calculated Cronbach's $\alpha$, which presents us with a measure of internal reliability between several items [47]. Cronbach's alpha coefficients and interpreted the values as follows: $\geq 0.90$, excellent; 0.80-0.89, good; 0.70-0.79, acceptable; 0.60-0.69, questionable; $0.50-0.59$, poor; and $<0.50$, unacceptable [48]. Correlations between items are an essential element in the analysis of the items representing a specific concept. Correlations between items examine the extent to which ratings of one item are related to ratings of all other scale items [49-51].

I-CVI represents the quotient between the number of experts who rated each question with a grade of 3 or 4 and between the number of all experts, which in our case was six $[42,44-46,52]$. The probability of agreement was calculated using the formula $\mathrm{Pc}_{\mathrm{C}}=[\mathrm{N} ! / \mathrm{A} !(\mathrm{N}-\mathrm{A}) !] 0,5 \mathrm{~N}$ where $\mathrm{N}$ represents the number of evaluators, and A represents the number of consents $[42,44-46,52,53]$. We used the following formula to calculate the kappa determination of the compliance agreement: $k=(I-C V I-P c) /\left(1-P_{c}\right)$. I-CVI represents item content validity index, and Pc represents the probability of chance agreement $[42,44-46,52]$. The S-CVI represents the proportion of questions rated by two experts with a score of 3 or $4[39,42,52]$.

\subsubsection{Perception of the Learning Environment}

The DREEM tool includes 50 items, 41 positive and nine negatives, related to learning perception (12 items), teacher perception (11 items), academic self-perception (eight items), atmospheric perception (12 items), and social self-perception (seven items). Each item is rated on a five-point Likert scale (from 1-strongly disagree to 5-strongly agree), where reverse-coding is used for nine statements [22,32]. Questions 4, 8, 9, 17, 25, 35, 39, 48, and 50 are reverse-coded $[22,32,54]$. The highest score indicates an ideal educational environment [22,32]. The categorization of the sub-scale for all items is as follows: lower than 50 represents a very poor level, range 51-75 is defined as a "plenty of problems" category, range 76-150 represents more positive than negative category, and higher than 150 represents an excellent score [35]. When analysing an individual item, it is necessary to pay attention to those with a mean score lower than 2 . There are also possible improvements in the measured assumptions with a mean score between 2 and 3 [55-57].

\subsection{Ethics of Research}

Before the research, we obtained ethical permission from the institutional ethical commission (No. 038/2020/2176-02/504). The authors of the questionnaire were asked for permission to use and translate it. Individuals who submitted responses to the online questionnaire also agreed to participate in the survey [22,23]. As part of the research, we sent students an invitation to participate in the research by e-mail. The online questionnaire also informed the participants about the purpose and goals of the research. Participants 
had the opportunity to refuse to participate in the anonymous survey. The survey was conducted from November 2020 until January 2021. We also informed them that we would use the results exclusively for research. In doing so, we will not disclose information from which the individuals involved could be identified. The risks and burdens of research are minimal.

\section{Results}

Of the 298 invited participants, 174 participants completed the questionnaire (response rate: $58.4 \%)$. Of these, $17 \%(n=30)$ were men and $83 \%(n=143)$ were women (one person did not specify their gender). The average age of the participants was 21.1 years $(\mathrm{SD}=3.96)$. The youngest person was 18 years old, and the oldest was 46 years old. Other basic characteristics of the students involved are shown in Table 1.

Table 1. Sample characteristics.

\begin{tabular}{cc}
\hline Gender & N (\%) \\
\hline Men & $30(17.2 \%)$ \\
\hline Female & $143(82.2 \%)$ \\
\hline Missing & $1(0.6 \%)$ \\
\hline Age & $\mathbf{M}$ (SD) \\
\hline Study program & $21.1(3.96)$ \\
\hline Undergraduate 1st degree study programme Nursing Care & $\mathbf{N ~ ( \% )}$ \\
\hline Postgraduate 2nd degree study programme Nursing Care & $167(96 \%)$ \\
\hline Postgraduate 3rd degree study programme Nursing Care & $3(1.7 \%)$ \\
\hline Missing & $2(1.1 \%)$ \\
\hline Study year & $2(1.1 \%)$ \\
\hline 1st year & $\mathbf{N ~ ( \% )}$ \\
\hline 2nd year & $86(49.4 \%)$ \\
\hline 3rd year & $59(33.9 \%)$ \\
\hline Senior & $23(13.2 \%)$ \\
\hline Missing & $5(2.9 \%)$ \\
\hline & $1(0.6 \%)$ \\
\hline
\end{tabular}

\subsection{DREEM Tool Validation Results}

The DREEM questionnaire was backtranslated from English into Slovenian by two experts. The content validity and reliability of the DREEM tool questionnaire in the Slovenian environment to assess the perception of the learning space in nursing students are presented below.

\subsubsection{Content Validity of the Questionnaire}

Table 2 presents the I-CVI, Pc, and $\mathrm{k}$ coefficient calculations for all questions in the DREEM tool. I-CVI for all questions in the Slovenian version of the questionnaire is acceptable. The I-CVI for all questions except question 20 was 1.000. The I-CVI for question twenty, "The teaching is well focused," was 0.833 . The probability of agreement on all questions is 0.016, and on the twentieth question, 0.094. Kappa on the determination of the agreement on adequacy for all questions is 1 . For the twentieth question, it is 0.816 . 
Table 2. Content validity of the DREEM tool.

\begin{tabular}{|c|c|c|c|c|c|c|c|}
\hline No. & Question(s) & $\mathbf{N}$ & A & I-CVI & Pc & $\mathbf{k}$ & Interpretation \\
\hline 1 & I am encouraged to participate in class. & 6 & 6 & 1.000 & 0.016 & 1.000 & Appropriate \\
\hline 2 & The teachers are knowledgeable. & 6 & 6 & 1.000 & 0.016 & 1.000 & Appropriate \\
\hline 3 & There is a good support system for students who get stressed. & 6 & 6 & 1.000 & 0.016 & 1.000 & Appropriate \\
\hline 4 & I am too tired to enjoy this course. & 6 & 6 & 1.000 & 0.016 & 1.000 & Appropriate \\
\hline 5 & Learning strategies which worked for me before continue to work for me now. & 6 & 6 & 1.000 & 0.016 & 1.000 & Appropriate \\
\hline 6 & The teachers are patient with patients. & 6 & 6 & 1.000 & 0.016 & 1.000 & Appropriate \\
\hline 7 & The teaching is often stimulating. & 6 & 6 & 1.000 & 0.016 & 1.000 & Appropriate \\
\hline 8 & The teachers ridicule the students. & 6 & 6 & 1.000 & 0.016 & 1.000 & Appropriate \\
\hline 9 & The teachers are authoritarian. & 6 & 6 & 1.000 & 0.016 & 1.000 & Appropriate \\
\hline 10 & I am confident about my passing this year. & 6 & 6 & 1.000 & 0.016 & 1.000 & Appropriate \\
\hline 11 & The atmosphere is relaxed during the ward teaching. & 6 & 6 & 1.000 & 0.016 & 1.000 & Appropriate \\
\hline 12 & This school is well timetabled. & 6 & 6 & 1.000 & 0.016 & 1.000 & Appropriate \\
\hline 13 & The teaching is student-centred. & 6 & 6 & 1.000 & 0.016 & 1.000 & Appropriate \\
\hline 14 & I am rarely bored on this course. & 6 & 6 & 1.000 & 0.016 & 1.000 & Appropriate \\
\hline 15 & I have good friends in this school. & 6 & 6 & 1.000 & 0.016 & 1.000 & Appropriate \\
\hline 16 & The teaching is sufficiently concerned to develop my competence. & 6 & 6 & 1.000 & 0.016 & 1.000 & Appropriate \\
\hline 17 & Cheating is a problem in this school. & 6 & 6 & 1.000 & 0.016 & 1.000 & Appropriate \\
\hline 18 & The teachers have good communications skills with patients. & 6 & 6 & 1.000 & 0.016 & 1.000 & Appropriate \\
\hline 19 & My social life is good. & 6 & 6 & 1.000 & 0.016 & 1.000 & Appropriate \\
\hline 20 & The teaching is well focused. & 6 & 5 & 0.833 & 0.094 & 0.816 & Appropriate \\
\hline 21 & I am feel am being well prepared for my profession. & 6 & 6 & 1.000 & 0.016 & 1.000 & Appropriate \\
\hline 22 & The teaching is sufficiently concerned to develop my confidence. & 6 & 6 & 1.000 & 0.016 & 1.000 & Appropriate \\
\hline 23 & The atmosphere is relaxed during lectures. & 6 & 6 & 1.000 & 0.016 & 1.000 & Appropriate \\
\hline 24 & The teaching time is put to good use. & 6 & 6 & 1.000 & 0.016 & 1.000 & Appropriate \\
\hline 25 & The teaching over-emphasizes factual learning. & 6 & 6 & 1.000 & 0.016 & 1.000 & Appropriate \\
\hline 26 & Last year work has been a good preparation for this year's work. & 6 & 6 & 1.000 & 0.016 & 1.000 & Appropriate \\
\hline 27 & I am able to memorize all I need. & 6 & 6 & 1.000 & 0.016 & 1.000 & Appropriate \\
\hline 28 & I seldom feel lonely. & 6 & 6 & 1.000 & 0.016 & 1.000 & Appropriate \\
\hline 29 & The teachers are good at providing feedback to students. & 6 & 6 & 1.000 & 0.016 & 1.000 & Appropriate \\
\hline 30 & There are opportunities for me to develop interpersonal skills. & 6 & 6 & 1.000 & 0.016 & 1.000 & Appropriate \\
\hline 31 & I have learned a lot about empathy in my profession. & 6 & 6 & 1.000 & 0.016 & 1.000 & Appropriate \\
\hline 32 & The teachers provide constructive criticism here. & 6 & 6 & 1.000 & 0.016 & 1.000 & Appropriate \\
\hline 33 & I feel comfortable in class socially. & 6 & 6 & 1.000 & 0.016 & 1.000 & Appropriate \\
\hline 34 & The atmosphere is relaxed during seminars/tutorials. & 6 & 6 & 1.000 & 0.016 & 1.000 & Appropriate \\
\hline 35 & I find the experience disappointing. & 6 & 6 & 1.000 & 0.016 & 1.000 & Appropriate \\
\hline 36 & I am able to concentrate well. & 6 & 6 & 1.000 & 0.016 & 1.000 & Appropriate \\
\hline 37 & The teachers give clear examples. & 6 & 6 & 1.000 & 0.016 & 1.000 & Appropriate \\
\hline 38 & I am clear about the learning objectives of the course. & 6 & 6 & 1.000 & 0.016 & 1.000 & Appropriate \\
\hline 39 & The teachers get angry in class. & 6 & 6 & 1.000 & 0.016 & 1.000 & Appropriate \\
\hline 40 & The teachers are well prepared for their class. & 6 & 6 & 1.000 & 0.016 & 1.000 & Appropriate \\
\hline
\end{tabular}


Table 2. Cont.

\begin{tabular}{lccccccc}
\hline No. & Question(s) & N & A & I-CVI & Pc & k & Interpretation \\
\hline 41 & My problem-solving skills are being well developed here. & 6 & 6 & 1.000 & 0.016 & 1.000 & Appropriate \\
\hline 42 & The enjoyment outweighs the stress of studying medicine. & 6 & 6 & 1.000 & 0.016 & 1.000 & Appropriate \\
\hline 43 & The atmosphere motivates me as a learner. & 6 & 6 & 1.000 & 0.016 & 1.000 & Appropriate \\
\hline 44 & The teaching encourages me to be an active learner. & 6 & 6 & 1.000 & 0.016 & 1.000 & Appropriate \\
\hline 45 & Much of what I have to learn seems relevant to a career in medicine. & 6 & 6 & 1.000 & 0.016 & 1.000 & Appropriate \\
\hline 46 & My accommodation is pleasant. & 6 & 6 & 1.000 & 0.016 & 1.000 & Appropriate \\
\hline 47 & Long-term learning is emphasized over short-term. & 6 & 6 & 1.000 & 0.016 & 1.000 & Appropriate \\
\hline 48 & The teaching is too teacher-centred. & 6 & 6 & 1.000 & 0.016 & 1.000 & Appropriate \\
\hline 49 & I feel able to ask the questions I want. & 6 & 6 & 1.000 & 0.016 & 1.000 & Appropriate \\
\hline 50 & The students irritate the teachers. & 6 & 6 & 1.000 & 0.016 & 1.000 & Appropriate \\
\hline
\end{tabular}

No. = Number of question; $\mathrm{N}$ = sample size; $\mathrm{A}$ = number of agreements; I-CVI = item content validity index; Pc = probability of chance agreement; $\mathrm{k}=$ kappa designating agreement on relevance.

The evaluation of two experts was included in the S-CVI assessment. None of them rated the question with a score of 1 or a score of 2 with a final S-CVI of 1.000 and is acceptable for the Slovenian environment (Table 3).

Table 3. Scale content validity of the DREEM tool.

\begin{tabular}{cccc}
\hline & Expert Ratter No. 1 & Expert Ratter No. 2 & Total \\
\hline Items rated 1 or 2 & 0 & 0 & 0 \\
\hline Items rated 3 or 4 & 50 & 50 & 100 \\
\hline Items rated 3 & 11 & 2 & 13 \\
\hline Items rated 4 & 39 & 48 & 87 \\
\hline S-CVI & $50 / 50=1.000$ & & \\
\hline
\end{tabular}

$\overline{\mathrm{S}-\mathrm{CVI}}=$ scale content validity.

\subsubsection{Reliability of the Questionnaire}

Supplementary Materials presents the correlations between the items in each scale in the DREEM tool questionnaire. Item correlations ranged between -0.038 and 0.620 .

Cronbach's alpha was 0.951, which indicates a high level of internal consistency. Table 4 represents the values of Cronbach's alpha with specific items deleted. Removing any question other than question 17, "Cheating is a problem in this school," and question 25 , "The teaching over-emphasizes factual learning," would reduce the value of Cronbach's alpha. Corrected item-total correlation for question 17 was 0.186 , and 0.192 for question 25 .

Table 4. Item-total statistics.

\begin{tabular}{ccccc}
\hline No. & $\begin{array}{c}\text { Scale Mean if } \\
\text { Item Deleted }\end{array}$ & $\begin{array}{c}\text { Scale Variance if } \\
\text { Item Deleted }\end{array}$ & $\begin{array}{c}\text { Corrected Item-Total } \\
\text { Correlation }\end{array}$ & $\begin{array}{c}\text { Cronbach's Alpha if } \\
\text { Item Deleted }\end{array}$ \\
\hline 1 & 127.8932 & 555.567 & 0.501 & 0.950 \\
\hline 2 & 126.6893 & 555.765 & 0.507 & 0.950 \\
\hline 3 & 127.9029 & 541.912 & 0.652 & 0.949 \\
\hline 4 & 127.9223 & 552.896 & 0.468 & 0.951 \\
\hline 5 & 127.0194 & 560.882 & 0.384 & 0.951 \\
\hline 6 & 126.7864 & 557.052 & 0.443 & 0.951 \\
\hline 7 & 127.2039 & 545.399 & 0.689 & 0.949 \\
\hline
\end{tabular}


Table 4. Cont.

\begin{tabular}{|c|c|c|c|c|}
\hline No. & $\begin{array}{l}\text { Scale Mean if } \\
\text { Item Deleted }\end{array}$ & $\begin{array}{l}\text { Scale Variance if } \\
\text { Item Deleted }\end{array}$ & $\begin{array}{c}\text { Corrected Item-Total } \\
\text { Correlation }\end{array}$ & $\begin{array}{l}\text { Cronbach's Alpha if } \\
\text { Item Deleted }\end{array}$ \\
\hline 8 & 126.5049 & 552.743 & 0.571 & 0.950 \\
\hline 9 & 127.6019 & 554.673 & 0.435 & 0.951 \\
\hline 10 & 126.7087 & 561.875 & 0.340 & 0.951 \\
\hline 11 & 127.1456 & 550.283 & 0.557 & 0.950 \\
\hline 12 & 128.0777 & 545.072 & 0.581 & 0.950 \\
\hline 13 & 127.2136 & 549.189 & 0.596 & 0.950 \\
\hline 14 & 127.5728 & 553.678 & 0.478 & 0.951 \\
\hline 15 & 126.5340 & 563.898 & 0.339 & 0.951 \\
\hline 16 & 126.7961 & 554.791 & 0.597 & 0.950 \\
\hline 17 & 126.9806 & 567.862 & 0.186 & 0.952 \\
\hline 18 & 126.6893 & 558.785 & 0.552 & 0.950 \\
\hline 19 & 126.8738 & 557.053 & 0.423 & 0.951 \\
\hline 20 & 126.9223 & 553.386 & 0.688 & 0.950 \\
\hline 21 & 126.9709 & 558.715 & 0.419 & 0.951 \\
\hline 22 & 127.1262 & 547.111 & 0.664 & 0.949 \\
\hline 23 & 126.8932 & 553.430 & 0.683 & 0.950 \\
\hline 24 & 126.7767 & 556.352 & 0.678 & 0.950 \\
\hline 25 & 128.3204 & 567.573 & 0.192 & 0.952 \\
\hline 26 & 126.8932 & 562.018 & 0.364 & 0.951 \\
\hline 27 & 127.4660 & 549.800 & 0.557 & 0.950 \\
\hline 28 & 127.1553 & 556.780 & 0.397 & 0.951 \\
\hline 29 & 126.8835 & 550.006 & 0.668 & 0.950 \\
\hline 30 & 126.8641 & 556.060 & 0.614 & 0.950 \\
\hline 31 & 126.5631 & 562.621 & 0.450 & 0.951 \\
\hline 32 & 126.9515 & 556.341 & 0.570 & 0.950 \\
\hline 33 & 126.5728 & 558.208 & 0.549 & 0.950 \\
\hline 34 & 126.6699 & 556.164 & 0.607 & 0.950 \\
\hline 35 & 127.0583 & 545.820 & 0.715 & 0.949 \\
\hline 36 & 127.1748 & 561.714 & 0.376 & 0.951 \\
\hline 37 & 126.8932 & 549.077 & 0.700 & 0.949 \\
\hline 38 & 126.9806 & 553.078 & 0.510 & 0.950 \\
\hline 39 & 126.8252 & 555.655 & 0.513 & 0.950 \\
\hline 40 & 126.8058 & 549.609 & 0.693 & 0.949 \\
\hline 41 & 126.9612 & 548.979 & 0.780 & 0.949 \\
\hline 42 & 127.4757 & 544.075 & 0.651 & 0.949 \\
\hline 43 & 127.2718 & 545.769 & 0.663 & 0.949 \\
\hline 44 & 127.2621 & 546.215 & 0.682 & 0.949 \\
\hline 45 & 126.9806 & 560.706 & 0.361 & 0.951 \\
\hline 46 & 126.3786 & 569.198 & 0.232 & 0.951 \\
\hline 47 & 127.0000 & 544.843 & 0.672 & 0.949 \\
\hline 48 & 127.1748 & 564.479 & 0.299 & 0.951 \\
\hline 49 & 126.7184 & 556.322 & 0.520 & 0.950 \\
\hline 50 & 126.7670 & 561.024 & 0.385 & 0.951 \\
\hline
\end{tabular}


Figure 1 presents a graph for screen analysis. The graph shows the eigenvalue scree plot for 50 instrument elements and points at one factor.

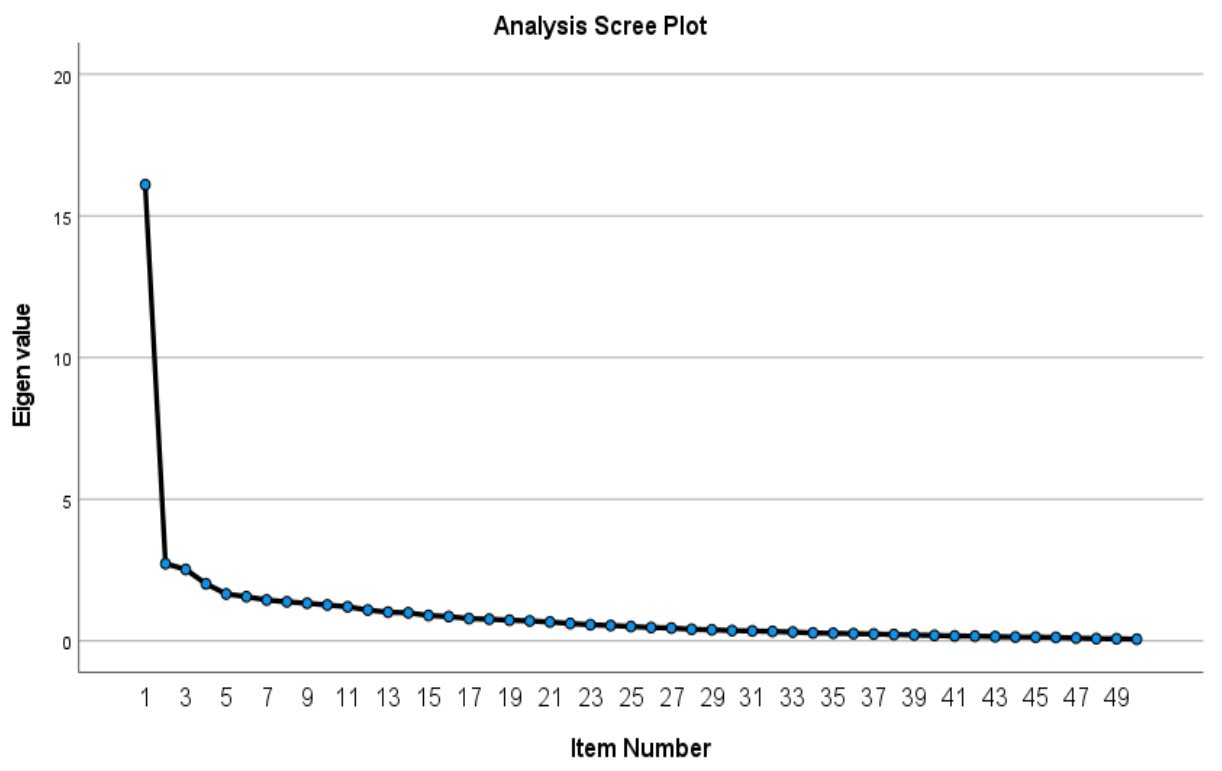

Figure 1. Analysis Scree Plot.

\subsection{Results of Perception of the Learning Environment}

Online teaching was perceived more positively than negatively. The mean assessment of student perception of learning is $28.1 / 48$, student perception of teachers is $28.9 / 44$, student academic self-perception is $19.8 / 32$, student perception of the atmosphere is $29.1 / 48$, and social self-perception of students is 16.5/28 (Table 5). All individual subscales are statistically related $(p<0.001)$.

Table 5. Mean score of DREEM tool.

\begin{tabular}{|c|c|c|c|c|c|c|}
\hline Subscale & Items & Total Score & Mean Score (SD) & Maximum Score & Minimum Score & Interpretation \\
\hline SPL & 12 & 48 & $28.1(7.92)$ & 47 & 3 & A more positive approach (25-36) \\
\hline SPT & 11 & 44 & $28.9(7.31)$ & 44 & 5 & Moving in the right direction (23-33) \\
\hline SAP & 8 & 32 & $19.8(5.26)$ & 32 & 4 & Feeling more on the positive side (17-24) \\
\hline SPA & 12 & 48 & $29.1(8.35)$ & 48 & 3 & A more positive atmosphere (25-36) \\
\hline SSP & 7 & 28 & $16.5(3.93)$ & 28 & 2 & Not too bad (15-21) \\
\hline Total & 50 & 200 & $122.2(30.66)$ & 196 & 20 & More positive than negative (101-150) \\
\hline
\end{tabular}

SPL = Students perception of learning; SPT = Students perception of teachers; SAP = Students academic self-perception; SPA = Students perceptions of atmosphere; SSP = Students social self-perceptions; SD = standard deviation.

Based on the Shapiro-Wilk test for women and the Kolmogorov-Smirnov test for men, we found that the individual values of the scales in students were unevenly distributed according to gender. Based on the Mann-Whitney U test, we identified a statistically significant relationship between the assessment of student perception of learning by gender $(\mathrm{U}=1346,500 ; p=0.024)$. The mean SPL score for men was $24.9 / 48$ (SD = 8.82). For women, this mean score was $28.9 / 48(\mathrm{SD}=7.27)$. There is no statistically significant difference by gender between the other subscales. Nevertheless, in all subscales, the scores were higher for women than for men: subscale SPT (29.3 vs. 28.1), subscale SAP (20.0 vs. 19.0), subscale SPA (29.4 vs. 28.6), and subscale SSP (16.4 vs. 16.6) (Figure 2).

To show the relationship between age and individual subscales, we performed a Pearson correlation test. The age of students is statistically significantly related to the SAP subscale score $(r=0.212 ; p=0.007)$ and the SPA subscale score $(r=9.213$; 0.007). 
Based on the Kruskal-Wallis test, we found that the study program attended by students affects the SAP score. The mean grade of SAP students attending the undergraduate first degree study program nursing care is $19.7 / 32(\mathrm{SD}=5.05)$, the score of students attending the postgraduate second degree study program nursing care is $25.67 / 32$ (1.53), and the score of students who attend a postgraduate third degree study program nursing care is $26 / 32(\mathrm{SD}=8.49)$.

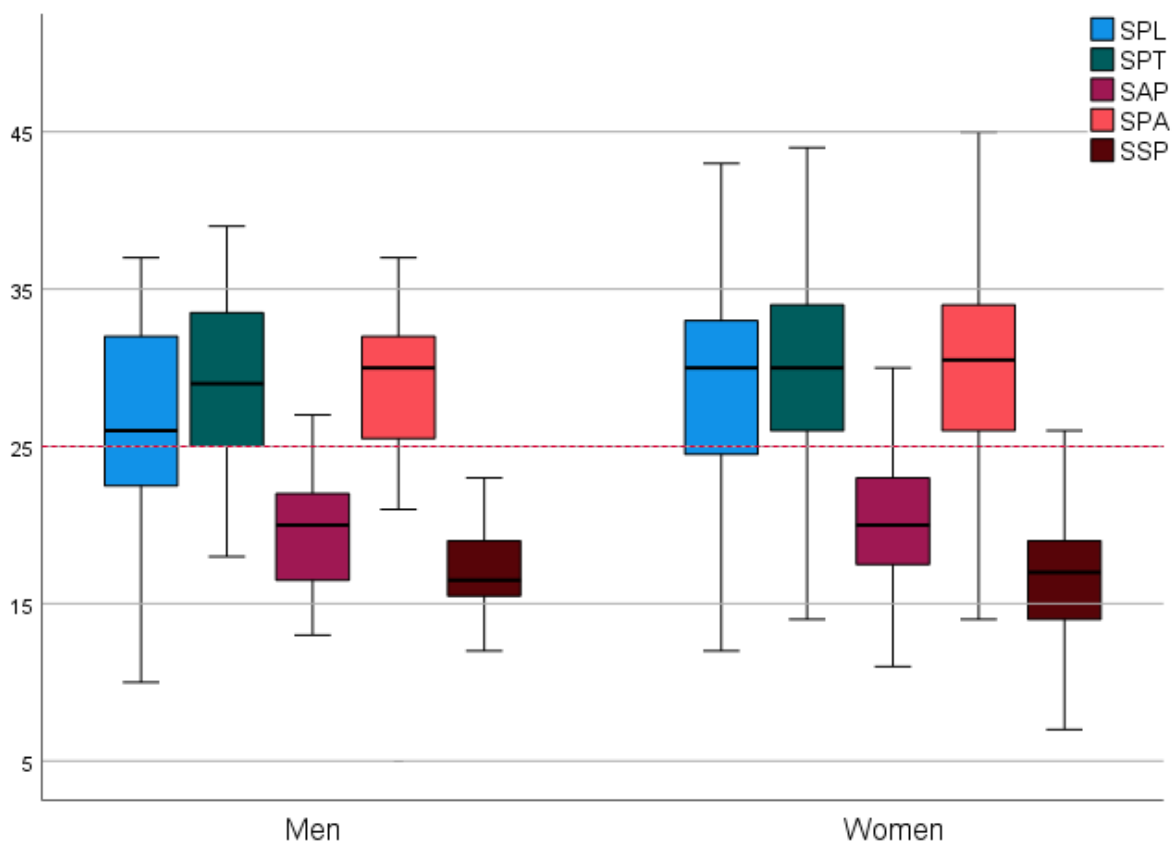

Figure 2. Gender comparison in subscales.

The mean assessment of student perception of learning is $28.1 / 48$, which means a more positive perception. Problematic assumptions with a mean grade of $\leq 2$ in the SPL subscale are "I am encouraged to participate in class," which has an average grade of $1.8(\mathrm{SD}=0.83$ ), and "The teaching over-emphasizes factual learning," which has a mean grade of $1.3(\mathrm{SD}=0.68)($ Table 6$) ; 69.2 \%$ of men $(n=18)$ and $64 \%$ of women $(n=80)$ agree that teachers being encouraging to participate. Table S1 in Supplementary Materials present the links between SPL items.

Table 6. Subscale SPL.

\begin{tabular}{cccc}
\hline No. & Question(s) & N & M (SD) \\
\hline 1 & I am encouraged to participate in class. & 160 & $1.8(0.83)$ \\
\hline 7 & The teaching is often stimulating. & 160 & $2.5(0.88)$ \\
\hline 13 & The teaching is student-centred. & 158 & $2.5(0.94)$ \\
\hline 16 & The teaching is sufficiently concerned to develop my competence. & 160 & $2.8(0.78)$ \\
\hline 20 & The teaching is well focused. & 159 & $2.7(0.70)$ \\
\hline 22 & The teaching is sufficiently concerned to develop my confidence. & 150 & $2.6(0.89)$ \\
\hline 24 & The teaching time is put to good use. & 152 & $2.9(0.61)$ \\
\hline 25 & The teaching over-emphasizes factual learning. & 151 & $1.3(0.68)$ \\
\hline 38 & I am clear about the learning objectives of the course. & 150 & $2.7(0.86)$ \\
\hline 44 & The teaching encourages me to be an active learner. & 147 & $2.4(0.91)$ \\
\hline 47 & Long-term learning is emphasized over short-term. & 147 & $2.7(0.95)$ \\
\hline 48 & The teaching is too teacher-centred. & 148 & $2.5(0.79)$ \\
\hline
\end{tabular}

No. = Number of question; $\mathrm{N}$ = sample size; $\mathrm{M}$ = mean; $\mathrm{SD}$ = standard deviation. 
The mean score of student perception of teachers is $28.9 / 44$, which means that it is moving in the right direction. The item "The teachers are authoritarian" received the lowest mean value of $1.9(\mathrm{SD}=0.98)$ (Table 7$) ; 39.4 \%$ of respondents $(n=62)$ do not agree with this statement, and $25.5 \%(n=48)$ neither agree nor disagree with this statement. Table S2 in Supplementary Materials present the links between SPT items.

Table 7. Subscale SPT.

\begin{tabular}{cccc}
\hline No. & Question(s) & N & M (SD) \\
\hline 2 & The teachers are knowledgeable. & 160 & $3.1(0.84)$ \\
\hline 6 & The teachers are patient with patients. & 148 & $2.9(0.88)$ \\
\hline 8 & The teachers ridicule the students. & 159 & $3.1(0.83)$ \\
\hline 9 & The teachers are authoritarian. & 174 & $1.9(0.98)$ \\
\hline 18 & The teachers have good communications skills with patients. & 144 & $3.0(0.69)$ \\
\hline 29 & The teachers are good at providing feedback to students. & 150 & $2.8(0.78)$ \\
\hline 32 & The teachers provide constructive criticism here. & 143 & $2.7(0.72)$ \\
\hline 37 & The teachers give clear examples. & 151 & $2.8(0.78)$ \\
\hline 39 & The teachers get angry in class. & 151 & $2.8(0.84)$ \\
\hline 40 & The teachers are well prepared for their class. & 151 & $2.9(0.79)$ \\
\hline 50 & The students irritate the teachers. & 147 & $2.9(0.83)$ \\
\hline
\end{tabular}

No. = Number of question; $\mathrm{N}$ = sample size; $\mathrm{M}$ = mean; $\mathrm{SD}$ = standard deviation.

The mean score of students' academic self-perception is $19.8 / 32$, representing that feelings are more on the positive side. None of the items in the SAP subscale received a lower mean score than 2 (Table 8). With the highest mean score, the item "I have learned a lot about empathy in my profession" stands out, with a mean score of 3.1 (SD = 0.65). A total of $89.9 \%$ of respondents $(n=134)$ agree that they learned a lot about empathy in the profession during their studies in the current year. Table S3 in Supplementary Materials present the links between SAP items.

Table 8. Subscale SAP.

\begin{tabular}{cccc}
\hline No. & Question(s) & N & M (SD) \\
\hline 5 & Learning strategies which worked for me before continue to work for me now. & 157 & $2.6(0.81)$ \\
\hline 10 & I am confident about my passing this year. & 161 & $2.9(0.84)$ \\
\hline 21 & I am feel am being well prepared for my profession. & 149 & $2.7(0.83)$ \\
\hline 26 & Last year work has been a good preparation for this year's work. & 113 & $2.7(0.81)$ \\
\hline 27 & I am able to memorize all I need. & 152 & $2.2(0.95)$ \\
\hline 31 & My problem-solving skills are being well developed here. & 174 & $3.1(0.65)$ \\
\hline 41 & Much of what I have to learn seems relevant to a career in medicine. & 146 & $2.7(0.74)$ \\
\hline 45 & I harned a lot about empathy in my profession. & $2.7(0.83)$ \\
\hline No. Number of question; N - sample size; M - mean; SD - standard deviation & 147
\end{tabular}

No. = Number of question; $\mathrm{N}$ = sample size; $\mathrm{M}=$ mean; $\mathrm{SD}=$ standard deviation.

A score of students' perceptions of the atmosphere is $29.1 / 48$, meaning that the atmosphere is more positive than negative. The lowest score was given to the statement "This school is well timetabled" and was $1.5(\mathrm{SD}=1.10)$ (Table 9$) ; 51.3 \%$ of respondents $(n=$ $81)$ disagree that the schedule is well planned, $25.9 \%(n=41)$ neither agree nor disagree with the statement. Table S4 in Supplementary Materials present the links between SPA items. 
Table 9. Subscale SPA.

\begin{tabular}{cccc}
\hline No. & Question(s) & N & M (SD) \\
\hline 11 & The atmosphere is relaxed during the ward teaching. & 144 & $2.5(0.95)$ \\
\hline 12 & This school is well timetabled. & 159 & $1.5(1.10)$ \\
\hline 17 & Cheating is a problem in this school. & 160 & $2.7(0.87)$ \\
\hline 23 & The atmosphere is relaxed during lectures. & 151 & $2.8(0.69)$ \\
\hline 30 & There are opportunities for me to develop interpersonal skills. & 152 & $2.7(0.74)$ \\
\hline 33 & I feel comfortable in class socially. & 151 & $3.0(0.69)$ \\
\hline 34 & The atmosphere is relaxed during seminars/tutorials. & 150 & $3.0(0.66)$ \\
\hline 35 & I find the experience disappointing. & 151 & $2.7(0.86)$ \\
\hline 36 & I am able to concentrate well. & 151 & $2.5(0.79)$ \\
\hline 42 & The enjoyment outweighs the stress of studying medicine. & 147 & $2.1(0.98)$ \\
\hline 43 & The atmosphere motivates me as a learner. & 147 & $2.4(0.96)$ \\
\hline 49 & I feel able to ask the questions I want. & 147 & $3.0(0.79)$ \\
\hline No. = Number of question; N = sample size; M = mean; SD = standard deviation. & &
\end{tabular}

The mean score of students' social self-perception is $16.5 / 28$, meaning that social perception is not too bad (Table 10). The item "There is a good support system for students who get stressed" and the item "I am too tired to enjoy this course" get a lower score of 2, more specifically $1.8(\mathrm{SD}=1.06)$ and $1.7(\mathrm{SD}=0.97) .43 .1 \%$ of the surveyed $(n=69)$ students are too tired to participate in the lectures. Table S4 in Supplementary Materials present the links between SPL items.

Table 10. Subscale SSP.

\begin{tabular}{cccc}
\hline No. & Question(s) & $\mathbf{N}$ & $\mathbf{M}(\mathrm{SD})$ \\
\hline 3 & There is a good support system for students who get stressed. & 161 & $1.8(1.06)$ \\
\hline 4 & I am too tired to enjoy this course. & 161 & $1.7(0.97)$ \\
\hline 14 & I am rarely bored on this course. & 159 & $2.1(0.95)$ \\
\hline 15 & I have good friends in this school. & 159 & $3.0(0.81)$ \\
\hline 19 & My social life is good. & 158 & $2.8(0.96)$ \\
\hline 28 & I seldom feel lonely. & 151 & $2.5(0.97)$ \\
\hline 46 & My accommodation is pleasant. & 146 & $3.2(0.67)$ \\
\hline
\end{tabular}

No. = Number of question; $\mathrm{N}$ = sample size; $\mathrm{M}$ = mean; $\mathrm{SD}$ = standard deviation.

Supplementary Materials represents the inter-item correlations of the subscale.

\section{Discussion}

To the best of the authors 'knowledge, this is the first study to assess students' perceptions of the educational environment in Slovenia. We wanted to obtain information to assess the learning environment of nursing students. Our study was conducted during the COVID-19 pandemic, when colleges were forced to move their education online. Thus, despite the challenges of social distancing, isolation, and quarantine measures [58], they continued to provide education for nurses [59].

The assessment of the learning environment in the nursing student participants of this study is more positive than negative, as in many studies where this tool was used $[15,35,54,60-68]$. So far, only one study has been conducted that provides researchers with insight into the differences between personal and online teaching. In the United Kingdom, researchers conducted a national cross-sectional study to assess the learning 
environment during online teaching. They found that the assessment of the learning environment was lower than in live teaching [21].

We wanted to assess if there are differences between individual scales according to gender. In our study, differences were detected only in the assessment of learning perception (SPL), where women had a higher score than men (28.9 for women vs. 24.9 for men, $p=0.024$ ). No statistically significant differences were detected in other subscales. The overall score is also higher for women (124.3; $\mathrm{SD}=29.04)$ compared with men (116.1; SD = 32.1). Similar results were also obtained in another study where researchers found higher scores in women than in men [62]. This means that women have a better perception of the educational environment. Studies detect gender differences in study habits, which in turn affect student outcomes [69]. Also, female students are more willing to participate and work in a team than male students [70]. There are also differences in the acceptance of e-learning between men and women [71]. In contrast to our study, however, Fooladi found that perceptions of the learning environment are lower in women among vulnerable groups [72].

There is no statistically significant difference between years of enrolment in our study. The highest DREEM score is detected in the first year of study, where the mean grade is 124.15 ( $\mathrm{SD}=31.89$ ). Other research finds that perception of the learning environment differs according to student performance, and also a difference between individual years of study [73]. Shrestha, et al., also note that the learning environment assessment is highest among students in the first year of study [74].

Of particular concern is that most students disagree with the claim that the schedule is well planned. Only $20.7 \%$ of respondents $(n=36)$ rate schedules as well-planned. This can also be related to the observation that $40.2 \%$ of students $(n=70)$ are often too tired to participate in lectures. Students are primarily concerned with time management in distance learning $[75,76]$. It is important to reduce the academic burden on students and help students develop time management skills, which significantly contributes to their success $[77,78]$. Stress and overload in nursing students can lead to burnout, anxiety, and depression [79].

Nebhinani, et al. point out that there is a great need to plan and implement various stress management programs [80]. Only $23.5 \%$ of respondents $(n=41)$ in our study agree that a good support system is in place in the presence of stress. Like our study, students in eastern Nepal perceived that they do not have a good support system during times of stress [74]. Numerous studies have found increased stress in students due to an outbreak of coronavirus disease $[10,81-83]$, so support in this area is particularly important at this time. Stress connected with distance learning for students mainly leads to a lack of concentration, motivation, and technical difficulties [84].

$56.3 \%$ of students $(n=98)$ believe that teachers focus too much on teaching based on data memorization, and $36.2 \%$ of students $(n=63)$ believe that teachers are too authoritative in their work. Nevertheless, most students $(n=117 ; 67.2 \%)$ believe that teaching is sufficiently focused on developing competencies related to their profession.

Health science students will receive such a good education, but its effectiveness must be rigorously and regularly evaluated [85]. Therefore, it is of the utmost importance that such research is continued, and the rate of improvement is assessed. Only in this way can we achieve the best possible learning environment for students.

\section{Limitations}

There is a possibility of bias due to low response to the survey questionnaire. The reason for this might be in the fact that questionnaires were sent to the students in an online form, which usually results in low response rates. The study also took place within one faculty and cannot be generalized on a wider scale. Also, the limitation is that the assessment of the educational environment was carried out only during online teaching and cannot be compared with the evaluation of the learning environment during the traditional implementation of the learning process. Another limitation is that the online survey was conducted only from November 2020 to January 2021 and not in other study periods. 


\section{Conclusions}

Nursing students generally rate their learning environment more positively than negatively, but there is still room for improvement in all categories. Greater emphasis is needed on the organization and timing of lessons to achieve better concentration of students in classes and reduce their level of stress. Educational organizations are also recommended to set up a good support system for students. The need to change the approach by teachers and their role was also perceived. With an authoritative approach and too much emphasis on factual learning, we negatively affect the student's motivation and willingness to work. Teachers can improve this through appropriate pedagogical and andragogic education.

It is important that learning organizations and teachers also focus on providing a suitable and appropriate learning environment for students during distance learning. This is the only way they can contribute to positive learning outcomes and gain student experience. However, this presents a unique challenge, as the teacher has no contact with students when teaching online.

In the future, we plan to conduct a longitudinal study to observe the impact and variation of different factors in assessment of the learning environment over time.

Supplementary Materials: The following are available online at https:/ / www.mdpi.com/article/10 $.3390 /$ healthcare $9080998 / \mathrm{s} 1$, Inter-item correlations of the subscale.

Author Contributions: Conceptualization, L.G., C.C., E.C., and G.Š.; Data curation, L.G., N.F., C.C., E.C., and G.Š.; Formal analysis, L.G. and G.Š.; Methodology, L.G., N.F., and G.Š.; Supervision, L.G. and G.Š.; Validation, L.G., N.F., and G.Š.; Visualization, L.G. and G.̌̌s; Writing—original draft, L.G. and G. ̌.; Writing-review \& editing, L.G., N.F., C.C., E.C., and G.Š. All authors have read and agreed to the published version of the manuscript.

Funding: The project “Digital Toolbox for Innovation in Nursing Education (I-BOX)" has been funded with support from the European Commission (2019-1-ES01-KA203-065836) under the Erasmus+ program. This publication reflects the views only of the authors, and the Commission cannot be held responsible for any use which may be made of the information contained therein. This study was also supported by the "knowledge through creative pathways 2016-2020" scheme cofunded by the European Union from the European Social Fund and the Republic of Slovenia and the Slovenian Research Agency (grant numbers N2-0101 and P2-0057).

Institutional Review Board Statement: The study was conducted according to the guidelines of the Declaration of Helsinki, and approved by the Ethics Committee of Faculty of Health Sciences, University of Maribor (038/2020/2176-02/504, 10.06.2020).

Informed Consent Statement: Participants agreed to participate in the research by completing and submitting a questionnaire.

Data Availability Statement: Data is currently not available for sharing, due to the further data collection process. Contact the first author for more information.

Conflicts of Interest: The authors declare no conflict of interest.

\section{References}

1. Pollard, C.A.; Morran, M.P.; Nestor-Kalinoski, A.L. The COVID-19 pandemic: A global health crisis. Physiol. Genom. 2020, 52, 549-557. [CrossRef] [PubMed]

2. Akande, O.W.; Akande, T.M. COVID-19 pandemic: A global health burden. Niger. Postgrad. Med. J. 2020, 27, 147. [CrossRef] [PubMed]

3. Alhajjaj, H.A. The effects of the covid-19 pandemic on students in Jordanian schools: A qualitative study. PalArchs J. Archaeol. Egypt/Egyptol. 2020, 17, 13787-13800.

4. Hiscott, J.; Alexandridi, M.; Muscolini, M.; Tassone, E.; Palermo, E.; Soultsioti, M.; Zevini, A. The global impact of the coronavirus pandemic. Cytokine Growth Factor Rev. 2020, 53, 1-9. [CrossRef] [PubMed]

5. Velikonja, N.K.; Erjavec, K.; Verdenik, I.; Hussein, M.; Velikonja, V.G. Association between preventive behaviour and anxiety at the start of the COVID-19 pandemic in Slovenia. Slov. J. Public Health 2020, 60, 17-24. [CrossRef]

6. Zadnik, V.; Mihor, A.; Tomsic, S.; Zagar, T.; Bric, N.; Lokar, K.; Oblak, I. Impact of COVID-19 on cancer diagnosis and management in Slovenia-preliminary results. Radiol. Oncol. 2020, 54, 329-334. [CrossRef] 
7. Rajab, M.H.; Gazal, A.M.; Alkattan, K. Challenges to online medical education during the COVID-19 pandemic. Cureus 2020, 12, e8966. [CrossRef]

8. OECD Policy Responses to Coronavirus. Strengthening Online Learning When Schools Are Closed: The Role of Families and Teachers in Supporting Students during the COVID-19 Crisis. Available online: http:/ /www.oecd.org/coronavirus/policyresponses/strengthening-online-learning-when-schools-are-closed-the-role-of-families-and-teachers-in-supporting-studentsduring-the-covid-19-crisis-c4ecba6c/ (accessed on 1 March 2021).

9. Mahdy, M.A.A. The impact of COVID-19 pandemic on the academic performance of veterinary medical students. Front. Vet. Sci. 2020, 7, 594261. [CrossRef] [PubMed]

10. Son, C.; Hegde, S.; Smith, A.; Wang, X.; Sasangohar, F. Effects of COVID-19 on college students' mental health in the United States: Interview survey study. J. Med. Internet Res. 2020, 22, e21279. [CrossRef] [PubMed]

11. Shawaqfeh, M.S.; Al Bekairy, A.M.; Al-Azayzih, A.; A Alkatheri, A.; Qandil, A.M.; A Obaidat, A.; Al Harbi, S.; Muflih, S.M. Pharmacy Students Perceptions of Their Distance Online Learning Experience During the COVID-19 Pandemic: A Cross-Sectional Survey Study. J. Med. Educ. Curric. Dev. 2020, 7, 2382120520963039. [CrossRef]

12. Bozkurt, A.; Sharma, R.C. Emergency remote teaching in a time of global crisis due to CoronaVirus pandemic. Asian J. Distance Educ. 2020, 15, i-vi.

13. Lawn, S.; Zhi, X.; Morello, A. An integrative review of e-learning in the delivery of self-management support training for health professionals. BMC Med. Educ. 2017, 17, 1-16. [CrossRef]

14. Dhawan, S. Online learning: A panacea in the time of COVID-19 crisis. J. Educ. Technol. Syst. 2020, 49, 5-22. [CrossRef]

15. Mukhtar, K.; Javed, K.; Arooj, M.; Sethi, A. Advantages, Limitations and Recommendations for online learning during COVID-19 pandemic era. Pak. J. Med. Sci. 2020, 36, S27. [CrossRef]

16. Tannenbaum, C.; Van Hoof, K. Effectiveness of online learning on health researcher capacity to appropriately integrate sex, gender, or both in grant proposals. Biol. Sex Differ. 2018, 9, 1-8. [CrossRef]

17. Gernsbacher, M.A. Why internet-based education? Front. Psychol. 2015, 5, 1530. [CrossRef] [PubMed]

18. Ellman, M.S.; Schwartz, M.L. Article Commentary: Online Learning Tools as Supplements for Basic and Clinical Science Education. J. Med. Educ. Curric. Dev. 2016, 3, JMECD-S1893. [CrossRef] [PubMed]

19. Radu, M.C.; Schnakovszky, C.; Herghelegiu, E.; Ciubotariu, V.A.; Cristea, I. The Impact of the COVID-19 Pandemic on the Quality of Educational Process: A Student Survey. Int. J. Environ. Res. Public Health 2020, 17, 7770. [CrossRef]

20. Regmi, K.; Jones, L. A systematic review of the factors-enablers and barriers-affecting e-learning in health sciences education. BMC Med. Educ. 2020, 20,1-18. [CrossRef]

21. Dost, S.; Hossain, A.; Shehab, M.; Abdelwahed, A.; Al-Nusair, L. Perceptions of medical students towards online teaching during the COVID-19 pandemic: A national cross-sectional survey of 2721 UK medical students. BMJ Open 2020, 10, e042378. [CrossRef]

22. Roff, S. The Dundee Ready Educational Environment Measure (DREEM) —A generic instrument for measuring students' perceptions of undergraduate health professions curricula. Med. Teach. 2005, 27, 322-325. [CrossRef] [PubMed]

23. Roff, S.; McAleer, S.; Harden, R.M.; Al-Qahtani, M.; Ahmed, A.U.; Deza, H.; Groenen, G.; Primparyon, P. Development and validation of the Dundee ready education environment measure (DREEM). Med. Teach. 1997, 19, 295-299. [CrossRef]

24. Irfan, F.; Al Faris, E.; Al Maflehi, N.; Karim, S.I.; Ponnamperuma, G.; Saad, H.; Ahmed, A.M. The learning environment of four undergraduate health professional schools: Lessons learned. Pak. J. Med. Sci. 2019, 35, 598. [CrossRef] [PubMed]

25. Aghamolaei, T.; Shirazi, M.; Dadgaran, I.; Shahsavari, H.; Ghanbarnejad, A. Health students' expectations of the ideal educational environment: A qualitative research. J. Adv. Med. Educ. Prof. 2014, 2, 151.

26. Ekstedt, M.; Lindblad, M.; Löfmark, A. Nursing students' perception of the clinical learning environment and supervision in relation to two different supervision models-A comparative cross-sectional study. BMC Nurs. 2019, 18, 1-12. [CrossRef]

27. Flott, E.A.; Linden, L. The clinical learning environment in nursing education: A concept analysis. J. Adv. Nurs. 2016, 72, 501-513. [CrossRef] [PubMed]

28. Helou, M.A.; Keiser, V.; Feldman, M.; Santen, S.; Cyrus, J.W.; Ryan, M.S. Student well-being and the learning environment. Clin. Teach. 2019, 16, 362-366. [CrossRef]

29. Polit, D.F.; Beck, C.T. Nursing Research: Principles and Methods; Lippincott Williams and Wilkins: Philadelphia, PA, USA, 2004.

30. Polit, D.F.; Beck, C.T. Nursing Research: Generating and Assessing Evidence for Nursing Practice; Lippincott Williams and Wilkins: Philadelphia, PA, USA, 2008.

31. Creswell, J.W. Educational Research: Planning, Conducting, and Evaluating Quantitative and Qualitative Research; Pearson: London, UK, 2004.

32. Riga, V.; Kossioni, A.; Lyrakos, G. Can DREEM Instrument (Dundee Ready Education Environment Measure) measure the learning environment in a School of Education? Educ. J. Univ. Patras UNESCO Chair 2015, 2, 59-69.

33. Whittle, S.R.; Whelan, B.; Murdoch-Eaton, D.G. DREEM and beyond; studies of the educational environment as a means for its enhancement. Educ. Health 2007, 20, 7.

34. Jeyashree, K.; Shewade, H.D.; Kathirvel, S. Development and psychometric testing of an abridged version of Dundee Ready Educational Environment Measure (DREEM). Environ. Health Prev. Med. 2018, 23, 1-6. [CrossRef]

35. Bhosale, U. Medical students' perception about the educational environment in western Maharashtra in medical college using DREEM scale. J. Clin. Diagn. Res. JCDR 2015, 9, JC01. [CrossRef] 
36. Colina, S.; Marrone, N.; Ingram, M.; Sánchez, D. Translation quality assessment in health research: A functionalist alternative to back-translation. Eval. Health Prof. 2017, 40, 267-293. [CrossRef]

37. Artino, A.R., Jr.; La Rochelle, J.S.; Dezee, K.J.; Gehlbach, H. Developing questionnaires for educational research: AMEE Guide No. 87. Med. Teach. 2014, 36, 463-474. [CrossRef] [PubMed]

38. Tsang, S.; Royse, C.F.; Terkawi, A.S. Guidelines for developing, translating, and validating a questionnaire in perioperative and pain medicine. Saudi J. Anaesth. 2017, 11, S80. [CrossRef]

39. Waltz, C.F.; Strickland, O.L.; Lenz, E.R. (Eds.) Measurement in Nursing and Health Research; Springer Publishing Company: New York, NY, USA, 2010.

40. Rubio, D.M.; Berg-Weger, M.; Tebb, S.S.; Lee, E.S.; Rauch, S. Objectifying content validity: Conducting a content validity study in social work research. Soc. Work Res. 2003, 27, 94-104. [CrossRef]

41. Yusoff, M.S.B. ABC of content validation and content validity index calculation. Resource 2019, 11, 49-54. [CrossRef]

42. Cilar, L.; Pajnkihar, M.; Štiglic, G. Validation of the Warwick-Edinburgh Mental Well-being Scale among nursing students in Slovenia. J. Nurs. Manag. 2020, 28, 1335-1346. [CrossRef]

43. Fijačko, N.; Fekonja, Z.; Denny, M.; Sharvin, B.; Pajnkihar, M.; Štiglic, G. Using content validity for the development of objective structured clinical examination checklists in a Slovenian Undergraduate Nursing program. In Teaching and Learning in Nursing; IntechOpen: London, UK, 2017.

44. Polit, D.F.; Beck, C.T. The content validity index: Are you sure you know what's being reported? Critique and recommendations. Res. Nurs. Health 2006, 29, 489-497. [CrossRef] [PubMed]

45. Polit, D.F.; Beck, T.; Owen, S.V. Focus on research methods is the CVI an acceptable indicator of content validity. Res. Nurs. Health 2007, 30, 459-467. [CrossRef]

46. Boateng, G.O.; Neilands, T.B.; Frongillo, E.A.; Melgar-Quiñonez, H.R.; Young, S.L. Best practices for developing and validating scales for health, social, and behavioral research: A primer. Front. Public Health 2018, 6, 149. [CrossRef] [PubMed]

47. Bujang, M.A.; Omar, E.D.; Baharum, N.A. A review on sample size determination for Cronbach's alpha test: A simple guide for researchers. Malays. J. Med. Sci. MJMS 2018, 25, 85. [CrossRef]

48. Balk, E.M.; Gazula, A.; Markozannes, G.; Kimmel, H.J.; Saldanha, I.J.; Resnik, L.J.; Trikalinos, T.A. Lower Limb Prostheses: Measurement Instruments, Comparison of Component Effects by Subgroups, and Long-Term Outcomes; Agency for Healthcare Research and Quality: Rockville, MD, USA, 2018.

49. Cohen, R.J.; Swerdlik, M.E.; Phillips, S.M. Psychological Testing and Assessment: An Introduction to Tests and Measurement; Mayfield Publishing Co.: California City, CA, USA, 1996.

50. Piedmont, R.L. Encyclopedia of quality of life and well-being research. In Inter-Item Correlations; Springer: Berlin/Heidelberg, Germany, 2014; pp. 3303-3304.

51. Piedmont, R.L.; Hyland, M.E. Inter-item correlation frequency distribution analysis: A method for evaluating scale dimensionality. Educ. Psychol. Meas. 1993, 53, 369-378. [CrossRef]

52. Vrbnjak, D.; Pahor, D.; Nelson, J.W.; Pajnkihar, M. Content validity, face validity and internal consistency of the Slovene version of Caring Factor Survey for care providers, caring for co-workers and caring of managers. Scand. J. Caring Sci. 2017, 31, 395-404. [CrossRef] [PubMed]

53. Larsson, H.; Tegern, M.; Monnier, A.; Skoglund, J.; Helander, C.; Persson, E.; Malm, C.; Broman, L.; Aasa, U. Content validity index and intra-and inter-rater reliability of a new muscle strength/endurance test battery for Swedish soldiers. PLoS ONE 2015, 10, e0132185. [CrossRef] [PubMed]

54. Al-Natour, S.H. Medical Students' Perceptions of their Educational Environment at a Saudi University. Saudi J. Med. Med. Sci. 2019, 7, 163. [CrossRef] [PubMed]

55. McAleer, S.; Roff, S. A practical guide to using the Dundee Ready Education Environment Measure (DREEM). AMEE Med. Educ. Guide 2001, 23, 29-33.

56. Miles, S.; Swift, L.; Leinster, S.J. The Dundee Ready Education Environment Measure (DREEM): A review of its adoption and use. Med. Teach. 2012, 34, e620-e634. [CrossRef] [PubMed]

57. Vaughan, B.; Carter, A.; Macfarlane, C.; Morrison, T. The DREEM, part 1: Measurement of the educational environment in an osteopathy teaching program. BMC Med. Educ. 2014, 14, 1-11. [CrossRef]

58. Dewart, G.; Corcoran, L.; Thirsk, L.; Petrovic, K. Nursing education in a pandemic: Academic challenges in response to COVID-19. Nurse Educ. Today 2020, 92, 104471. [CrossRef] [PubMed]

59. Morin, K.H. Nursing education after COVID-19: Same or different? J. Clin. Nurs. 2020, 29, 3117-3119. [CrossRef] [PubMed]

60. Al-Mohaimeed, A. Perceptions of the educational environment of a new medical school, Saudi Arabia. Int. J. Health Sci. 2013, 7, 150. [CrossRef] [PubMed]

61. Badiee Aval, S.; Morovatdar, N. Perceptions of Students toward the Educational Environment Based on the DREEM Tool in a New Nursing Scholl in Iran. J. Patient Saf. Qual. Improv. 2018, 6, 1-6.

62. Bakhshialiabad, H.; Bakhshi, G.; Hashemi, Z.; Bakhshi, A.; Abazari, F. Improving students' learning environment by DREEM: An educational experiment in an Iranian medical sciences university (2011-2016). BMC Med. Educ. 2019, 19, 1-10. [CrossRef] [PubMed]

63. Edgren, G.; Haffling, A.C.; Jakobsson, U.L.F.; Mcaleer, S.; Danielsen, N. Comparing the educational environment (as measured by DREEM) at two different stages of curriculum reform. Med. Teach. 2010, 32, e233-e238. [CrossRef] [PubMed] 
64. Farooq, S.; Rehman, R.; Hussain, M.; Dias, J.M. Comparison of undergraduate educational environment in medical and nursing program using the DREEM tool. Nurse Educ. Today 2018, 69, 74-80. [CrossRef]

65. Hamid, B.; Faroukh, A.; Mohammadhosein, B. Nursing students' perceptions of their educational environment based on DREEM model in an Iranian university. Malays. J. Med. Sci. MJMS 2013, 20, 56.

66. Hongkan, W.; Arora, R.; Muenpa, R.; Chamnan, P. Perception of educational environment among medical students in Thailand. Int. J. Med. Educ. 2018, 9, 18. [CrossRef]

67. Keskinis, C.; Bafitis, V.; Karailidou, P.; Pagonidou, C.; Pantelidis, P.; Rampotas, A.; Sideris, M.; Tsoulfas, G.; Stalkos, D. The use of theatre in medical education in the emergency cases school: An appealing and widely accessible way of learning. Perspect. Med. Educ. 2017, 6, 199-204. [CrossRef]

68. Ogun, O.A.; Nottidge, T.E.; Roff, S. Students' perceptions of the learning environment in two Nigerian medical schools offering different curricula. Ghana Med. J. 2018, 52, 116-121. [CrossRef]

69. Alzahrani, S.S.; Soo Park, Y.; Tekian, A. Study habits and academic achievement among medical students: A comparison between male and female subjects. Med. Teach. 2018, 40, S1-S9. [CrossRef]

70. Wilhelmsson, M.; Ponzer, S.; Dahlgren, L.O.; Timpka, T.; Faresjö, T. Are female students in general and nursing students more ready for teamwork and interprofessional collaboration in healthcare? BMC Med. Educ. 2011, 11, 1-10. [CrossRef] [PubMed]

71. Ramírez-Correa, P.E.; Arenas-Gaitán, J.; Rondán-Cataluña, F.J. Gender and acceptance of e-learning: A multi-group analysis based on a structural equation model among college students in Chile and Spain. PLoS ONE 2015, 10, e0140460.

72. Fooladi, M.M. Gender influence on nursing education and practice at Aga Khan university school of nursing in Karachi, Pakistan. Nurse Educ. Pract. 2008, 8, 231-238. [CrossRef] [PubMed]

73. Ahmed, Y.; Taha, M.H.; Al-Neel, S.; Gaffar, A.M. Students' perception of the learning environment and its relation to their study year and performance in Sudan. Int. J. Med. Educ. 2018, 9, 145. [CrossRef]

74. Shrestha, E.; Mehta, R.S.; Mandal, G.; Chaudhary, K.; Pradhan, N. Perception of the learning environment among the students in a nursing college in Eastern Nepal. BMC Med. Educ. 2019, 19, 1-7. [CrossRef] [PubMed]

75. Fidalgo, P.; Thormann, J.; Kulyk, O.; Lencastre, J.A. Students' perceptions on distance education: A multinational study. Int. J. Educ. Technol. High. Educ. 2020, 17, 1-18. [CrossRef]

76. Parker, E.B.; Howland, L.C. Strategies to manage the time demands of online teaching. Nurse Educ. 2006, 31, 270-274. [CrossRef]

77. Ghiasvand, A.M.; Naderi, M.; Tafreshi, M.Z.; Ahmadi, F.; Hosseini, M. Relationship between time management skills and anxiety and academic motivation of nursing students in Tehran. Electron. Physician 2017, 9, 3678. [CrossRef]

78. Quina Galdino, M.J.; Preslis Brando Matos de Almeida, L.; Ferreira Rigonatti da Silva, L.; Cremer, E.; Rolim Scholze, A.; Trevisan Martins, J.; Haddad, F.L.; do Carmo, M. Burnout among nursing students: A mixed method study. Investig. Educ. Enferm. 2020, 38, e07. [CrossRef] [PubMed]

79. Chaabane, S.; Chaabna, K.; Bhagat, S.; Abraham, A.; Doraiswamy, S.; Mamtani, R.; Cheema, S. Perceived stress, stressors, and coping strategies among nursing students in the Middle East and North Africa: An overview of systematic reviews. Syst. Rev. 2021, 10, 1-17. [CrossRef]

80. Nebhinani, M.; Kumar, A.; Parihar, A.; Rani, R. Stress and coping strategies among undergraduate nursing students: A descriptive assessment from Western Rajasthan. Indian J. Community Med. Off. Publ. Indian Assoc. Prev. Soc. Med. 2020, 45, 172. [CrossRef] [PubMed]

81. Aiyer, A.; Surani, S.; Gill, Y.; Ratnani, I.; Sunesara, S. COVID-19 anxiety and stress survey (cass) in high school and college students due to coronavirus disease 2019. Chest 2020, 158, A314. [CrossRef]

82. Lai, A.Y.K.; Lee, L.; Wang, M.P.; Feng, Y.; Lai, T.T.K.; Ho, L.M.; Lam, V.S.F.; Ip, M.S.M.; Lam, T.H. Mental health impacts of the COVID-19 pandemic on international university students, related stressors, and coping strategies. Front. Psychiatry 2020, 11, 584240. [CrossRef]

83. Rodríguez-Hidalgo, A.J.; Pantaleón, Y.; Dios, I.; Falla, D. Fear of COVID-19, Stress, and Anxiety in University Undergraduate Students: A Predictive Model for Depression. Front. Psychol. 2020, 11, 3041. [CrossRef] [PubMed]

84. Lischer, S.; Safi, N.; Dickson, C. Remote learning and students' mental health during the Covid-19 pandemic: A mixed-method enquiry. Prospects 2021, 1-11. [CrossRef]

85. Khalil, R.; Mansour, A.E.; Fadda, W.A.; Almisnid, K.; Aldamegh, M.; Al-Nafeesah, A.; Alkhalifah, A.; Al-Wutayd, O. The sudden transition to synchronized online learning during the COVID-19 pandemic in Saudi Arabia: A qualitative study exploring medical students' perspectives. BMC Med. Educ. 2020, 20, 1-10. [CrossRef] 